ISSN : $2302-1590$

E-ISSN: $2460-190 \mathrm{X}$

ECONOMICA

Journal of Economic and Economic Education Vol.2 No.2 (99 - 105)

\title{
PENGARUH MOTIVASI MEMASUKI DUNIA KERJA DAN PENGALAMAN PRAKTIK KERJA INDUSTRI TERHADAP KOMPETENSI KERJA PESERTA DIDIK KELAS XII SMK MUHAMMADIYAH I PADANG TAHUN PELAJARAN 2012/2013
}

\author{
Rahmi Yati \\ Mahasiswa Program Studi Pendidikan Ekonomi STKIP- PGRI Sumbar \\ J1. Gunung Pangilun No.1, Padang Sumatera Barat \\ Email: yati.rahmi@yahoo.com \\ Ansofino \\ Dosen Program Studi Pendidikan Ekonomi STKIP- PGRI Sumbar \\ Jl. Gunung Pangilun No.1, Padang Sumatera Barat \\ Email: ansofino2001@yahoo.com \\ Submited: 2014.03.13 Reviewed: 2014.04.02 Accepted: 2014.04.12 \\ http://dx.doi.org/10.22202/economica.2014.v2.i2.222
}

\begin{abstract}
Core problem in this research is do motivation enter world work and experience of industrial practice have an effect on to interest work student of SMK Muhammadiyah I Padang. Technique analyse data use multyregression with test of signifikan use t test $f$ test. Result of this research indicate that,: Motivation enter job world have positive and significant effect to interest work student. This matter is shown with motivation coefficient value enter world work equal to 0,325. industrial practice have positive and significant effect to interest work student. This matter is shown with coefficient value experience of industrial practice equal to 0,435. Inferential that motivation enter world work and experience of industrial practice by together have positive and significant effect to interest work. This research implies motivation go to school and old fellow motivate student need more improved to student motivation enter higher corporate world. School to optimize management of expense and time of industrial practice of student so that reaching of one of the intention of industrial practice
\end{abstract}

\section{Abstrak}

Pokok persoalan yang diteliti pada skripsi ini adalah apakah motivasi memasuki dunia kerja dan pengalaman praktek kerja industri berpengaruh terhadap kompetensi kerja siswa SMK Muhammadiyah I Padang.Teknik analisis data menggunakan regresi berganda dengan uji signifikan menggunakan uji $t$ dan uji $F$ sedangkan uji asumsiklasik menggunakan uji Normalitas, uji Heterokedastisitas dan uji Multikolonieritas. Hasil penelitian ini menunjukkan bahwa,: Motivasi memasuki dunia kerja berpengaruh signifikan dan positif terhadap kompetensi kerja siswa. Hal ini ditunjukkan dengan nilai koefisien motivasi memasuki dunia kerja sebesar 0,325. Praktik kerja industri berpengaruh signifikan dan positif terhadap kompetensi kerja siswa. Hal ini ditunjukkan dengan nilai koefisien pengalaman praktik kerja industri sebesar 0,435. Dapat disimpulkan bahwa motivasi memasuki dunia kerja dan pengalaman praktik kerja industri secara bersama-sama berpengaruh signifikan dan positif terhadap kompetensi kerja siswa.Implikasi dari penelitian ini adalah dorongan dari pihak sekolah dan orang tua memotivasi siswa perlu lebih ditingkatkan agar motivasi siswa memasuki dunia usaha lebih tinggi. Pihak sekolah agar mengoptimalkan pengelolaan waktu dan biaya praktik kerja industri siswa supaya tercapainya salah satu tujuan dari praktik kerja industri adalh efisiensi proses pendidikan .

Keywords: motivation, experience, work competence 
PENDAHULUAN

Pendidikan

Kejuruan

merupakanpendidikan menengah yang mempersiapkan peserta didik untuk bekerja dalambidang tertentu(UU Sistem Pendidikan Nasional atau UUSPN No 20 tahun 2003 pasal 15 ). Untuk menunjang tujuan ini, dirancang Pendidikan SistemGanda (PSG) sebagai perwujudan kebijaksanan dan Link and Match.Dalamprosesnya, PSG ini dilaksanakan pada lembaga (tempat) yaitu di sekolah dandi dunia kerja.Upaya ini dilakukan dalam rangka meningkatkan mutu tamatanSMK dalam menciptakan relevansi pendidikan dengan tuntutan kebutuhantenaga kerja. Kompetensi lulusan pendidikan kejuruan sebagai subsistem dari pendidikan nasional menurut Depdikbud 2001 ( UUSPN 20 th 2003) adalah :

Penghasil tamatan yang memiliki keterampilan dan penguasaanIPTEK dengan bidang dari tingkat keahlian yang sesuai dengan kebutuhan pembangunan.

1. Penghasil tamatan yang memiliki kemampuan produktif,penghasil sendiri, mengubah status tamatan dari status beban menjadi aset bangsa yang mandiri.

2. Penghasil pengggerak perkembangan industri Indonesia yang

3. Penghasil tamatan dan sikap mental yang kuat untuk dapat mengembangkan dirinya secara berkelanjutan.

Pengangguran tamatan SMK di Sumatera Barat dari tahun 2009 - tahun 2012 berada pada tingkat $6,76 \%$ sampai $10,10 \%$, sementara pengangguran tamatan SMU dari tahun 2009 sampai tahun 2012 berada pada tingkat $9,43 \%$ sampai $20,39 \%$. Berdasarkan data diatas, persentase pengangguran tamatan SMK lebih sedikit bila dibandingkan persentase pengangguran tamatan SMU.Hal ini menunjukkan kompetensi kerja siswa SMK lebih bagus bila dibandingkan dengan kompetensi kerja SMU.
Kompetensi kerja adalah suatu kemampuan untuk melaksanakan atau melakukan suatu pekerjaan atau tugas yang dilandasi atas keterampilan dan pengetahuan serta didukung oleh sikap kerja yang dituntut oleh pekerjaan tersebut (Wibowo 2011:324).Dengan demikian, kompetensi menunjukkan keterampilan atau pengetahuan yang dicirikan oleh profesionalisme dalam suatu bidang tertentu sebagai sesuatu yang terpenting, sebagai unggulan bidang tersebut.

Menurut Berelson dalam Meidawati (2010:113) mendifinisikan motivasi sebagai keadaan kejiwaan dan sikap mental yang memberikan energy, mendorong kegiatan (moves), dan menyalurkan perilaku ke arah mencapai kebutuhan yang memberikan kepuasan atau mengurangi ketidak seimbangan.Motivasi tersebut timbul akibat adanya berbagai kebutuhan, kebutuhan dapat berujud fisik,biologis, sosial ekonomi dan sosial psikis. Yang lebih penting adalah bersifat psikis, misalnya penghargaan, pengakuan, keselamatan, perlindungan ,keamanan,jaminan sosial dan sebagainya.

Menurut Uno (2010: 10) Motivasi merupakan dorongan internal dan eksternal dalam diri seseorang untuk mengadakan perubahan tingkah laku, yang mempunyai indikator adanya keinginan untuk melakukan kegiatan, adanya dorongan dan kebutuhan melakukan kegiatan, adanya harapandan cita-cita, adanya penghormatan atas diri, adanya lingkungan yangbaik dan adanya kegiatan yang menarik.Hal inilah yang jadi indikator motivasi memasuki dunia kerja dalam penelitian ini.

Dalam Kurikulum Dikmenjur 2008, praktek kerja industri adalah pola penyelenggaraan diklat yang dikelola bersama-sama antara SMK dengan industri/asosiasi profesi sebagai Institusi Pasangan (IP), mulai dari tahap perencanaan, pelaksanaan hingga evaluasi dan sertifikasi yang merupakan satu kesatuan program dengan menggunakan berbagai bentuk alternative pelaksanaan 
seperti day release, block release, dan sebagainya.

Kemudian dalam jurnal program Prakerin (1999: 1) dijelaskan bahwa Prakerin adalah suatu komponen praktek keahlian profesi, berupa kegiatan secara terprogram dalam situasi sebenarnya untuk mencapai tingkat keahlian dan sikap kerja professional yang dilakukan di industri.

Menurut Dalyono (2005: 167), pengalaman dapat mempengaruhifisiologi perkembangan individu yang merupakan salah satu prinsipperkembangan kesiapan (readiness) peserta didik SMK dalammempersiapkan diri memasuki dunia kerja. Pengalaman merupakanpengetahuan atau keterampilan yang sudah diketahui dan dikuasaiseseorang sebagai akibat perbuatan atau pekerjaan yang telahdilakukan sebelumnya selama jangka waktu tertentu.Jadi seseorangbaru dapat dikatakan berpengalaman jika memiliki tingkatpenguasaan dan keterampilan yang banyak serta sesuai denganbidang pekerjaannya.

Menurut Wena (1996: 226) mengungkapkan bahwapenyelenggaraan pendidikan dan pelatihan dengan PendidikanSistem Ganda bertujuan untuk

(1). Menghasilkan tenaga kerja yang memiliki keahlian profesional, yaitu tenaga kerja yang memiliki tingkat pengetahuan,

keterampilan, dan etos kerja yang sesuai dengan tuntutan lapangan kerja.

(2). Meningkatkan dan memperkokoh keterkaitan dan kesepadanan (link and match) antara lembaga pendidikan pelatihan kejuruan dan dunia kerja

(3). Meningkatkan efisiensi proses pendidikan dan pelatihan tenaga kerja berkualitas dan profesional.

(4). Memberi pengakuan dan penghargaan terhadap pengalaman kerja sebagai proses dari pendidikan.Hal inilah yang menjadi inidikator dalam penelitian ini.

\section{Kerangka Konseptual}

Motivasi Memasuki Dunia Kerja adalah sesuatu yang menimbulkan semangat atau dorongan peserta didik untuk memasuki dunia kerja, baik yang berasal dari dalam diri ataupun dari luar diri peserta didik.Motivasi Memasuki Dunia Kerja dapat diukur dengan indikator adanya hasrat dan keinginan untuk melakukan kegiatan, adanya dorongan dan kebutuhan untuk melakukan kegiatan, adanya harapan dan citi-cita, adanya penghargaan dan penghormatan atas diri,adanya lingkungan yang baik dan kegiatan yang menarik. Semakin tinggi Motivasi Memasuki Dunia Kerja akanmenyebabkan kompetensi Kerja peserta didik menjadi tinggi dan sebaliknya,semakin rendah Motivasi Memasuki Dunia Kerja akan menyebabkanKompetensi Kerja peserta didik menjadi rendah.

Pengalaman Praktik Kerja Industri adalah pengetahuan atauketerampilan yang diketahui dan dikuasai peserta didik setelah mengikutipraktik kerja di dunia usaha atau dunia industri selama jangka waktutertentu.Pengalaman Praktek Kerja Indistri dapat diukur dengan indikator menghasilkan tenaga kerja yang profesioal meningkatkan dan memperkokoh keterkaitan dan kesepadanan (link and match), meningkatkan efisiensi proses pendidikan dan memberikan pengakuan dan penghargaan terhadap pengalaman kerja.

\begin{tabular}{lrr}
\multicolumn{2}{c}{ Kompetensikerja } & adalah \\
kemampuan & seseorang untuk \\
menyelesaikan & suatu pekerjaan & yang
\end{tabular}
dilandasi atas pengetahuan serta didukung oleh sikap kerja yang dituntut oleh pekerjaan tersebut..Kompetensi kerja sangat penting dimiliki oleh seorang peserta didik SMK, karenapeserta didik SMK merupakan harapan masyarakat untuk menjadi lulusanSMK yang mempunyai kemampuan sesuai dengan bidang keahliannya. Kompetensi kerja 
diukur dengan menggunakan indikator ,intelejensi, keterampilan, keyakinan akan nilai dan karakteristik kepribadian menurut Zwell dalam Wibowo (2011:339)
Pengaruh Motivasi Memasuki Dunia Kerja dan Pengalaman Praktek Kerja lapangan terhadap kompetensi kerja siswa dapat diyatakan dalam bagan ini.

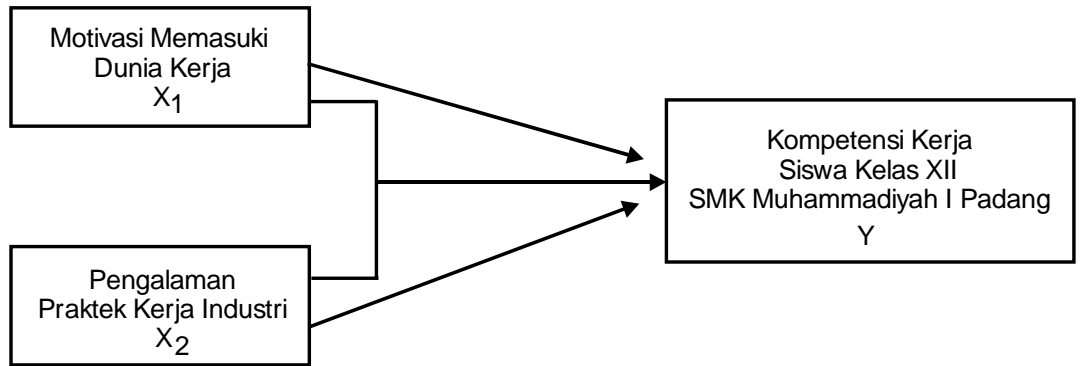

Gambar 1. Kerangka konseptual

\section{Hipotesis Penelitian}

Berdasarkan kajian pustaka, penelitian sebelumnya dan kerangka berpikiryang telah diuraikan, maka dapat diajukan hipotesis sebagai berikut.

1. Motivasi memasuki dunia kerja berpengaruh signifikan terhadap

kompetensi kerja peserta didik kelas XII SMK Muhammadiyah I Padang

2. Pengalaman praktik kerja industri berpengaruh signifikan terhadap

kompetensi kerja peserta didik kelas XII SMK Muhammadiyah I Padang.

3. Motivasi memasuki dunia kerja dan pengalaman praktik kerja industri berpengaruh signifikan terhadap kompetensi kerja peserta didik kelas XII

SMK Muhammadiyah I Padang.

\section{METODE PENELITIAN}

Penelitian ini merupakan penelitian deskriptif kuantitatif.Penelitian ini dilaksanakan di SMK Muhammadiyah I Padang pada bulan Agustus 20013.Populasi dalam penelitian ini adalah seluruh siswa kelas XIIprogram teknik kendaraan ringan yang berjumlah 60 orang. Penelitian ini merupakan penelitian populasi.Dari jumlah 60siswa program teknik kendaraan ringan tersebut semuanyadiambil sebagai responden penelitian.Teknik pengumpulan data menggunakan angket.Instrumen yang digunakan dalam penelitian ini adalah angket tertutup,yaitu angket yang telah dilengkapi dengan alternatif jawaban, sehinggaresponden tinggal memilih salah satu jawaban yang telah disediakan.Instrumen angket ini digunakan untuk memperoleh data mengenai Motivasi Memasuki Dunia Kerja $\left(\mathrm{X}_{1}\right)$, Pengalaman Praktik Kerja Industri. $\left(\mathrm{X}_{2}\right)$ dan Kompetensi Kerja (Y). Pertanyaan yang disusun sebagai instrument penelitian menggunakan 4 alternatif jawaban, yaitu sangat setuju, setuju,kurang setuju, tidak setuju atau selalu, sering, jarang, tidak pernah.

Angket dilakukan pengujian vakiditas dan reabilitas. Tekinik analisa data menggunakan analisa deskriptif, inferensial dan uji hipotesis.

\section{PEMBAHASAN}

Data penelitian yang akan dideskripsikan terdiri dari dua jenis variabel yaitu variabel bebas dan variabel terikat. Variabel bebas dalam penelitian ini adalah motivasi memasuki dunia kerja $\left(\mathrm{X}_{1}\right)$, dan praktik kerja industri $\left(\mathrm{X}_{2}\right)$. Sedangkan variabel terikat dalam penelitian ini adalah kompetensi kerja siswa SMK Muhammadiyah I Padang (Y). Untuk motivasi memasuki dunia kerja $\left(\mathrm{X}_{1}\right)$ terdiri dari 22 item pernyataan, untuk praktek kerja industri $\left(\mathrm{X}_{2}\right)$ terdiri dari 16 item pernyataan dan kompetensi kerja siswa (Y) terdiri dari 16 item pernyataan. Hasil analisis deskriptif untuk setiap variabel penelitian rata-rata berada pada kategori baik. 


\section{Analisis Inferensial}

\section{a.Uji Persyaratan Asumsi Klasik}

1. Uji Normalitas

Pengujian normalitas data berikut histogram residualnya digunakan untuk mengetahui distribusi sebuah data yang mempunyai pola seperti distribusi normal.

\section{Uji heteroskedastisitas}

Uji heteroskedastisitas adalah dengan membandingkan nilai $\mathrm{X}^{2}$ hitung (nilai Obs* $\mathrm{R}$ squared) dengan nilai $\mathrm{X}^{2}$ tabel dengan derajat kepercayaan $\alpha 5 \%$. Nilai $X^{2}$ tabel adalah 9,49. Hasil uji heteroskedastisitas nilai $\mathrm{X}^{2}$ hitung adalah $6,39<X^{2}$ tabel 9,49 maka dapat disimpulkan model lolos uji heteroskedastisitas.

\section{3)Uji Multikolinearitas}

Uji multikolinearitas bertujuan untuk menguji apakah dalam model regresi terbentuk ada korelasi yang tinggi atau sempurna diantara variabel bebas atau tidak. Jika model regresi terbentuk ada korelasi yang tinggi diatara variabel bebas maka model regresi dinyatakan mengandung gejala multikolinearitas.Bila nilai $\mathrm{R}_{1}^{2}>$ nilai $\mathrm{R}_{1.1}^{2} \mathrm{R}_{1.2}^{2}$ maka model regresi tidak ditemukan multikolinearitas.Bila nilai $\mathrm{R}_{1}^{2}<$ nilai $\mathrm{R}_{1.1}^{2} \quad \mathrm{R}_{1.2}^{2}$ maka model terdapat multikolinearitas. Berdasarkan hasil estimasi regresi X2, R-squared $\left(\mathrm{R}^{2}{ }_{1.2}\right)$ adalah 0,257.Berdasarkan tabel 5.20, 5.21dan 5.22 nilai $\mathrm{R}^{2}$ adalah 0,792, nilai $\mathrm{R}_{1.1}^{2}$ dan nilai $\mathrm{R}_{1.2}^{2}$ adalah samasama 0,527 maka dapat disimpulkan $0,792>0,527$ maka tidak ditemulan multikolinearitas antar variabel.

\section{b.Analisis regresi berganda}

Analisis regresi linear berganda bertujuan untuk melihat pengaruhmotivasi memasuki dunia kerja dan pengalaman praktik kerja industri terhadap kompetensi kerja siswa. Dari analisis data yang dilakukan dengan eviewsdapat disajikan hasil regresi $\mathrm{Y}=9,295+0,325 \mathrm{X}_{1}+$ $0,435 \mathrm{X}_{2}+e_{i}$

Nilai konstanta yang diperoleh sebesar 9,295. Hal ini berarti bahwa jika variabel motivasi memasuki dunia kerja dan pengalaman praktik kerja industri adalah 0, maka kompetensi kerja (Y) nilainya adalah 9,295.Koefisien regresi variabel motivasi memasuki dunia kerja $\left(\mathrm{X}_{1}\right)$ sebesar 0,325 , artinya jika variabel independen lain nilainya tetap dan motivasi memasuki dunia kerja mengalami kenaikan sebesar 1satuan, maka minat kompetensi kerja siswa akan mengalami peningkatan sebesar 0,325satuan. Koefisien tersebut bernilai positif artinya terjadi hubungan positif antara motivasi memasuki dunia kerja dengan kompetensi kerja siswa, semakin kuat motivasi memasuki dunia kerja maka semakin tinggi kompetensi kerja siswa.

Koefisien pengalaman praktik kerja industri $\left(\mathrm{X}_{2}\right)$ sebesar 0,435 , artinya jika variabel independen lain nilainya tetap dan pengalaman praktik kerja industri mengalami kenaikan sebesar 1satuan, maka kompetensi kerja akan mengalami peningkatan sebesar 0,434 satuan. Koefisien tersebut juga bernilai positif artinya terjadi hubungan positif antara pengalaman praktik kerjaindustri dengan kompetensi kerja siswa, semakin kuat pengaruh pengalaman praktik kerja industri maka semakin tinggi kompetensi kerja siswa.

\subsection{Uji Hipotesis.}

\section{1)Uji F}

Berdasarkan analisis data dengan eviews, diketahui bahwa nilai $F_{\text {hitung }}$ adalah 109,3.. Sementara nilai $F_{\text {tabel }}$ 3,18. Dari kedua nilai tersebut diperoleh perbandingan $\quad \mathrm{F}_{\text {hitung }}>\mathrm{F}_{\text {tabel }} \quad 109,3>$ 3,18. Hal ini menunjukkan bahwa motivasi memasuki dunia kerja dan pengalaman praktik kerja industri berpengaruh secara signifikan dan positif terhadap kompetensi kerja siswa. Semakin kuat motivasi memasuki dunia kerja dan pengalaman praktek kerja industri maka akan semakin kuat pula kompetensi kerja siswa. Berdasarkan analisis diatas dan hasil penelitian terlihat jelas motivasi memasuki dunia kerja dan pengalaman praktek kerja industriberpengaruh signifikan terhadapkompetensi kerja siswa SMK Muhammadiyah I Padang. 


\section{2) Uji t}

Untuk mengetahui kebenaran hipotesis yang diajukan, maka akan diuji parameter hipotesis dengan menggunakan uji $t$, uji $t$ diperlukan untuk melihat pengaruh antara masing - masing variabel independen terhadap variabel dependen. Tingkat kesalahan $(\propto)$ dalam uji t ini adalah $5 \%$ dengan ketentuan nilai prob< 0,05 maka $\mathrm{H}_{0}$ ditolak dan $\mathrm{H}_{1}$ diterima, sebaliknya nilai prob $>0,05$ maka $\mathrm{H}_{0}$ diterima dan $\mathrm{H}_{1}$ ditolak.

Dari hasil uji $t$ dengan menggunakan software eviews diketahui nilai probabilitas 0,005 , dari kedua nilai tersebut diperoleh perbandingan $0,005<$ 0,05 . Artinya variabel motivasi memasuki dunia kerja mempengaruhi secara signifikan terhadap kompetensi kerja secara parsial.Artinya apabila motivasi memasuki dunia kerja meningkat sebesar 1 satuan maka akan mendorong kenaikan kompetensi kerja siswa sebesar 0,32 satuan.Variabel pengalaman praktek kerja industri nilai prob yaitu 0,005 maka dari kedua nilai tersebut diperoleh perbandingan $0,005<0,05$.Artinya pengalaman praktik kerja industri mempengaruhi secara signifikan terhadap kompetensi kerja siswa secara parsial. Artinya apabila pengalaman praktik kerja industri bertambah sebesar 1 satuan maka akan mendorong peningkatan kompetensi kerja sebesar 0,43 satuan.

\section{3) Uji Koefisien Determinasi} Hasil estimasi dengan menggunakan software eviews diperoleh nilai $\mathrm{R}^{2}=0,793$ menandakan bahwa variasi dari perubahan kompetensi kerja siswa (Y) mampu dijelaskan secara serentak oleh variabel-variabel motivasi memasuki dunia kerja $\left(X_{1}\right)$ dan pengalaman praktik kerja industri $\left(\mathrm{X}_{2}\right)$ sebesar $79,30 \%$, sedangkan sisanya sebesar $20,70 \%$ dijelaskan oleh faktor-faktor lain yang tidak masuk dalam model.

\section{PENUTUP}

\section{Kesimpulan}

Berdasarkan hasil analisis yang berkaitan dengan tujuan penelitian ini, maka dapat ditarik beberapa kesimpulan hasil penelitian sebagai berikut:

1. Motivasi memasuki dunia kerja berpengaruh signifikan dan positif terhadap kompetensi kerja siswa kelas XII program teknik kendaraan ringan SMK Muhammadiyah I Padang. Hal ini ditunjukkan dengan nilai koefisien motivasi memasuki dunia kerja sebesar 0,325.Berarti setiap kenaikan motivasi memasuki dunia kerja siswa sebesar 1 satuan maka kompetensi kerja akan mengalami peningkatan sebesar 0,325 satuan

2. Pengalaman praktik kerja industri berpengaruh signifikan dan positif terhadap kompetensi kerja siswa kelas XII program teknik kendaraan ringanSMK Muhammadiyah I Padang.Hal ini ditunjukkan dengan nilai koefisien pengalaman praktik kerja industri sebesar 0,435.Berarti setiap kenaikan pengalaman praktek kerja industri sebesar 1 satuan maka kompetensi kerja akan mengalami peningkatan sebesar 0,435 satuan.

3. Berdasarkan hasil penelitian ini dapat disimpulkan bahwa motivasi memasuki dunia kerja dan pengalaman praktek kerja industri secara bersama-sama berpengaruh signifikan dan positif terhadap kompetensi kerja siswa kelas XII program teknik kendaraan ringan SMK Muhammadiyah I Padang. Hal ini ditunjukkan oleh nilai $F$ hitung sebesar 109,3 lebih besar dibandingkan dengan nilai $\mathrm{f}$ tabel sebesar5,24 dengan tingkat kesalahan $5 \%$.

\section{DAFTAR PUSTAKA}

10.22202/economica.2014.v2.i2.222 
Anoraga,Panji(2009). Psikologi Kerja. Jakarta: Rineka Cipta.

Arikunto (1998).Prosedur Penelitian Suatu Pendekatan Praktek. Jakarta:Rineka Cipta

Arikunto (2010).Prosedur Penelitian Suatu Pendekatan Praktek. Jakarta:Rineka Cipta

Badan Pusat Statistik (2011). Sumatera Barat Dalam Angka.Padang:BPS Sumbar

Barthos, Basir (2009). Manajemen Sumber Daya ManusiaJakarta: PT Bumi Aksara.

Chalpin, J.P (2006). Kamus Lengkap Psikologi Pendidikan (terjemahan Kartini Kartono). Jakarta: Rineka Grafindo Persada

Dalyono (2005) Psikologi Pendidikan.Jakarta : Rineka Cipta

Djaali (2007).Psikologi Pendidikan, Jakarta. Bumi Aksara

Hamalik,Oemar (2007) Manajemen Ketenagakerjaan. Jakarta, Bumi Aksara

Hasan,Iqbal(2004). Analisis Data Penelitian dengan Statistik. Jakarta. PT. Bumi Aksara.

Maidawati, SE, MSi. (2010). Pengantar Manajemen.Padang. Publit IAIN-IB Pres.

Muslisch, Masnur (2011).KTSP Pembelajaran Berbasis Kompetensi dan Konstektual. Jakarta: Bumi Aksara.

P, Siagian, MPA (2004). Teori Motivasi $\checkmark$ danAplikasinya.Jakarta.PT. Rineka Cipta.

Purwanto, Ngalim (2006) Psikologi Pendidikan.Bandung. Remaja Rosdakarya

Sardiman A.M(2009) Interaksi dan motivasi Belajar Mengajar, Jakarta. Raja Grafindo Perkasa.

Setyaprabowo, Padadan (2007). Skripsi Pengaruh Pengalaman Praktek Kerja Industri dan Motivasi memasuki Dunia Kerja Terhadapa Kompetensi
Kerja Kelas XII Keahlian Akuntansi SMKN Purworejo. Yokyakarta

Siagian, Sondang (2004). Teori Motivasi IdanAplikasinya.Jakarta.PT. Rineka Cipta.

Soehartono,Irawan (2008).Metode Penelitian Sosial.Bandung. Remaja Rosdakarya.

Sudjana(1992) Metode

Statistik,Bandung.Transito

Sugiyono (2009) Metode Penelitian Kualitatif Kuantitatif. Bandung. Alfabetas

Suliyanto (2011) Ekonometrika Terapan Teori dan Aplikasi dengan SPSS.Yokyakarta. Andy

Sulistyarini, Emi Prabawati Dwi (2012). Skripsi “ Pengaruh Motivasi Memasuki Dunia Kerja dan Pengalaman Praktek Kerja Industri Terhadap Kompetensi Kerja Peserta Didik Kelas XII Program

Keahlian Akuntansi SMK Negeri I Tempel".UNY

Suparji, Avida Arisandi (2012) Abstrak "Pengaruh Praktek Kerja Industri Terhadap Kompetensi Kerja Siswa Siswa SMKN I Sidoarjo".UNS

Syaodih, Nana (2009). Landasan Psikologi dan Proses

Pendidikan.Bandung.Remaja Rosdakarya

Uno,B Hamzah (2012). Teori Motivasi dan Pengukurannya.Jakarta:Bumi

Aksara.

Wena Made (1996). Pendidikan sisitim ganda.Bandung . Tarsito

Wibowo, (2011). Manajemen kinerja. Jakarta: PT. Raja Grafindo Persada. 